\title{
Impact of Activity-Based Map Literacy Skills Teaching on Academic Achievement Levels of Secondary School Students in Kazakhstan
}

\author{
Raziya KALDYBEKOVA ${ }^{1}$ \\ Abai Kazakh National Pedagogical University, Almaty \\ KAZAKSTAN
}

\author{
Bülent AKSOY2 \\ Gazi University, Ankara, TURKEY
}

\section{Bahadurkhan ABDYMANAPOV ${ }^{3}$ \\ Abai Kazakh National Pedagogical University, Almaty KAZAKSTAN}

${ }^{1}$ Corresponding author: PhD Student. Abai Kazakh National Pedagogical University, Almaty KAZAKSTAN . razia-75[at] mail.ru. ORCID: 0000-0003-1751-6962

2 Prof. Dr. Gazi University, Faculty of Education, Department of Social Studies Education, Ankara, TURKEY. baksoy28 [at] gmail.com. ORCID: 0000-0002-7181-8008

${ }_{3}^{3}$ Assoc. Prof.. Abai Kazakh National Pedagogical University, Department of Geography, Ecology and Tourism, Almaty, KAZAKSTAN. global.eco[at] mail.ru. ORCID: 0000-0003-2141-9858

\section{Abstract}

The aim of this research is to determine the impact of activity-based teaching on students' map literacy academic achievements in teaching secondary school seventh grade map skills subjects. The research was carried out in a semiexperimental design model with a pretest-posttest control group. The academic achievement test, consisting of a total of 12 items at three different difficulty levels, was used as a data collection tool in the study. The developed measurement tools were applied to 61 people from seventh grade students studying in thirteen different secondary schools located in Talgar district in Almaty region of Kazakhstan. Directional variance analysis (repeated measures) technique was used for repeated measurements on a single factor to solve the sub-problems of the study. According to the results of the research, easy, medium difficulty, difficult questions and total test scores of the experimental group students who applied the activity-based learning model and the control group students who applied the program-based learning were found to be similar according to the group variable. In contrast, easy, medium difficulty, difficult questions and total test scores related to map skill subjects of experimental group students and control group students were found to be significant in favor of experimental group according to the measurement variable and the common effect of group*measurement factors. In other words, activity-based map skills teaching applied to the experimental group is more effective in increasing the academic success of secondary school seventh graders in map skills than Program-based teaching applied to the control group. Accordingly, it is recommended that secondary school students acquire map skills while enriching these skills with activities.

\section{Keywords}

Map, Map Skills, Secondary School Students, Semi-Experimental Design 
Map, or the area of interest of living in the whole of human, or in part, the physical details of these details of events and phenomena that occur in this area or details, details, usually on a flat surface, is a representation of a certain scale. Details and information are displayed with symbols, and orientation and location according to a reference system are also performed (Tokpanov \& Mazbayev, 2012). Maps are an effective tool for storing and communicating spatial information. Maps are of great importance for the daily life of people as well as for the study of geography (Salishhev, 1990; Zarutskaya and Svatkova, 1982). Learning-teaching process, tourist trips, transportation, scientific research, interpretation of physical characteristics, direction finding, location analysis, distance and area calculation, spatial planning, etc. maps are used for many purposes (Tümertekin and Özgüç, 2000). The maps are the materials needed on land, at sea, in the shipment of military units, on camping trips, when flying in an airship, and in creating a walking route (Vostokova et al., 2002; Gryunberg et al.,1991). Maps are needed by people of different professions, including meteorologists, astronauts, sailors, pilots (Lyutyj, 2002). What do maps mean? An innocent photograph of geography, a scientific representation, or images of our minds? If it wasn't for the maps, we might have a hard time creating an image of where we live in our minds. For example, How could we have known that Cambodia looked like a mare's head in the corridor, Turkey in the Mediterranean? Therefore, maps are an integral part of our mind, social sciences and earth sciences (Aksoy, 2019).

Map skills for the 11-14 age group are generally included in the geography and Social Studies courses programs. In Kazakhstan, subjects related to map skills are given at the basic level in primary school, while the geography course of secondary school is included in the curriculum in more detail. It is very important to develop the skills of using and analyzing maps in geography courses in secondary schools (Zhemerov, 2011; Kussainov, 2012). Map literacy is a theoretical and complex situation for secondary school children. In particular, it is necessary to know theoretical and applied skills as well as other cartographic features to work with topographic maps (Sukhinin, 2019; Bibik, 1975; Kudinov, 2017). Map literacy is important for perceiving the shape of life, relative size, and objects that students remember, whether they can clearly imagine in their minds (Klimanovoy\&Naumova, 2002; Alimzhanova, 2011). Activities on topographic maps and geographical atlases are of great importance in the formation of map literacy (Jemirova, 2017).

Along with developments in education and technology in the twenty-first century, literacy standards for various subjects or disciplines are being set. Kress (2003) defines the concept of literacy as" the ability to effectively use communicative symbols given meaning by society." The place of reading symbols in the alphabet is taken by literatures who understand that they are reading and who are able to produce information with this competence. One of these types of literacy is map literacy. Map literacy is defined as the ability to use maps in everyday life and understand maps. But on map literacy, researchers suggest different views. Olson (1976) identified three levels of map literacy that became progressively more difficult: comparing individual symbol properties, recognizing the properties of symbol groups on the map as a whole, and using maps as a tool for structuring 
knowledge in decision-making. Buckley, Muehrcke, and Muehrcke (1978) characterize map literacy as three phases consisting of map reading, map analysis, and map interpretation. Weeden (1997) classifies map skills as using maps, making maps, reading maps, and interpreting maps. Map literacy consists of information, understanding, application, analysis, synthesis and evaluation steps (Clarke, 2003). Koç and Demir (2014) have divided map competencies into four categories: ability to process maps, read and interpret maps, draw draft maps, and use maps on the scale they developed to measure map literacy of individuals. They determined the map information using a multiple-choice test. Map competencies and map knowledge together constitute haita literacy. Rautencbach, Coetzee and Çöltekin (2017) examine map skills in six categories: recognizing symbols, determining direction and route, locating, measuring and predicting, calculating and explaining, and interpreting. Mcclure (1992) is correct map skills concrete from the abstract; 1) the ability to interpret the meaning of symbols, 2) profiling skills: skills profiling, 3) navigational skills, 4) distance, area, and slope measurement skills, 5) the ability to determine coordinate and location, 6) the ability to use scale, 7) the ability to define the physical properties and creating a map draft 8) map reading and interpretation skills in the form of eight steps.

Several researchers have conducted studies on map skills and map literacy (Carswell 1971; Gilmartin \& Patton 1984; Liben and Downs, 1989; Gerberve Wilson, 1989; McClure, 1992; Wood, 1992; White, 1995; Weeden, 1997; Catling, 1998; Clarke, 2003; MacEachren, 2004; Wiegand, 2006; Kızılçaoğlu, 2007; Golledge, Marsh, \& Battersby, 2008; Richard B. Schultz, Joseph J. Kerski and Todd C. Patterson, 2008; Koç, 2008; Koç, 2010; Buckley, Muehrcke \& Muehrcke, 2011; Sönmez \& Aksoy, 2012; Aksoy, 2013; Sönmez \& Aksoy (2013); Gökçe, 2015; Koç \& Karatekin, 2015; Aksoy, Kılıçoğlu \& Ablak, 2015; Koç, Aksoy \& Çifçi 2017, Aksoy \& Koç, 2017; Kartal \& Koç, 2017, Erol, 2017, Aksoy, 2019; Aksoy and Ablak, 2019; Kaldybekova\& Beykitova, 2019; Isatayeva \& Tukhtasinov, 2020; Kaldybekova \& Abdymanapov, 2020).

\section{Aim of Research and Sub-Problems}

The aim of this research is to determine the impact of activity-based teaching on the academic achievement of students' map literacy skills in teaching secondary school seventh grade map skills subjects. The research looked for answers to the following sub-problems:

1. Easy question test scores differ according to a) groups (experiment-control), b) measurements (pretest-posttest) and c) group*the common effect of measurement factors?

2. Map skills of experimental group students where an activity-based learning model is applied and control group students where a program-based learning model is applied medium difficulty question test scores differ according to a) groups (experiment-control), b) measurements (pretest-posttest) and c) group*the common effect of measurement factors?

3. Map skills of experimental group students who apply an activity-based learning model and control group students who apply a program-based 
learning model difficult question test scores differ according to a) groups (experiment-control), b) measurements (pretest-posttest) and group*measurement factors?

4. Are the total scores of the map skill test of the experimental group students to whom the activity-based learning model is applied and the control group students to whom the program-based learning model is applied differ according to a) groups (experiment-control), b) measurements (pretestposttest) and c) group*measurement factors?

\section{Methodology}

\section{Research Design}

The effect of activity-based map skills teaching on academic success was carried out using the semi-experimental design with the pretest-posttest control group. A semi-experimental design is a design used in many studies, especially in the area of education, when all variables cannot be controlled (Cohen, Manion \& Marrison, 2000). In this design, there is an experiment and a control group, but in the selection of experiment and control groups, no random assignment is made and the equality of the groups is emphasized (Fraenkel \& Wallen, 2006). Preliminary testing is applied primarily to the created experimental and control groups. Materials whose effect will be studied in the experimental group; no intervention is made in the control group. After application, the final test is applied to both groups and the research is terminated in this way (Lodico, Spaulding \& Voegtle, 2006).

\section{Working Group}

The appropriate sampling method was used in the creation of the working group. The study's working group consists of 60 secondary school seventh graders studying in 13 secondary schools in Talgar district center in Almaty region of Kazakhstan in the fall semester of the 2019-2020 academic year. 60 students were selected by researchers and an expert delegation on a voluntary basis from seventh grade branches in thirteen different schools in the secondary school where the study group will be implemented as a priority. Of these selected students, 29 of the experiments and 31 were assigned as control groups.

\section{Application}

In the study, the map skills academic achievement test consisting of three different difficulty levels (easy-medium-difficult) was started by applying pretest to the students in the experimental and control group. The practice continued for a total of six weeks, including two hours per week. Applications carried out in the experimental group were processed according to the course flow plan enriched with activity-based tests; in the control group, they were processed according to the program-based learning model. In this context, students in the experimental group were given an activity application with questions aimed at improving their map skills, starting from easy to medium difficulty and going to difficult during the twohour lesson every week. At the end of the six-week practice, the experimental and control groups underwent an academic achievement test of map skills consisting of 
three different difficulty levels (easy-medium-difficult), and the research was completed.

\section{Data Collection}

Map skills academic achievement test (AAT). For the Academic Achievement Test (AAT) prepared by the researchers, the attainments related to the map included in the seventh-grade geography course curriculum were examined and the scope validity of the prepared questions were taken into account. Researchers identified six sets of tests for use in the study: Fedorova (2015), Beysenbayeva (2015), Yevdokimov (2011), Beysenbayeva, Kotyakhova \& Larionova (2009), Petrova (1999), and Petrova (1999). The researchers created the measurement tool by selecting twelve test questions (easy, medium, and difficult) with different degrees of difficulty from each of the tests mentioned above. In order to determine the validity of the scope of the questions contained in the prepared academic achievement test, three teachers and a teacher who are experts in map subjects were presented and experts were asked for their opinion on the test. After expert opinions, it was decided that twelve questions remained in the academic achievement test. Multiple-choice questions were used in the academic achievement test, and one score was given for each correct answer given in the assessment of the test, and zero score was given for answers left incorrect or blank. The reliability coefficients of the success test were determined by referencing the values in the pilot studies of the researchers who developed the test.

\section{Data Analysis}

In the study, two-way ANOVA (repeated measures) technique was used for repeated measurements on a single factor in solving sub-problems. AAT total scores and difficulty dimensions (easy-medium-difficult) scores were examined based on skewness and kurtosis coefficients and Kolmogrov-Smirnov test in order to test the normality assumption from the requirements of the statistical technique used in the research. "According to Tabachnick and Fidell (2013), it shows normal distribution if the skewness and kurtosis coefficients of variables are in the range of \pm 2 ". "In this context, it was determined that the data showed normal distribution. In this case, it seems that the two-way ANOVA test for repeated measurements on the single factor used in the analysis of the data provides one of the basic assumptions".

One of the main assumptions for two-way ANOVA analysis for repeated measurements is the homogeneity of the variances. For this purpose, Levene test results of dependent variables were examined. According to the results of the levene test, it can be said that it provides the assumption of homogeneity of the variances related to the pretest-posttest scores, which are dependent variables, in all dimensions of difficulty.

\section{Findings}

\section{Findings and Comments on the First Sub-Problem}

In the analysis of the first sub-problem of the study, it was investigated whether the map skill of experimental and control group students differed according to the 
easy question test scores according to groups (experiment-control), measurements (pretest-posttest) and their common effect. The results of the analysis are given in Table-1-2. Pretest-posttest average score and standard deviation values obtained by students from the map skill easy success test are given in Table 1.

Table 1

Pretest-Posttest Average Score and Standard Deviation Values That Student Receive From the Map Skills Easy Success Test

\begin{tabular}{lllllll}
\hline \multirow{2}{*}{ Group } & \multicolumn{3}{l}{ Pretest } & \multicolumn{5}{c}{ Posttest } \\
\cline { 2 - 7 } & $\mathrm{N}$ & $\overline{\mathrm{X}}$ & $\mathrm{S}$ & $\mathrm{N}$ & $\overline{\mathrm{X}}$ & $\mathrm{S}$ \\
\hline Experimental & 29 & 14.55 & 4.63 & 29 & 16.62 & 3.96 \\
\hline Control & 31 & 14.23 & 5.13 & 31 & 14.84 & 5.07 \\
\hline
\end{tabular}

As can be seen in table 1, the average score for the easy success test before the experiment was $=14.55$ of the students of the experimental group who applied the teaching model based on map activities, while this value was $=16.62$ after the experiment. The same scores of students in the control group where program-based teaching is applied are $=14.23$ and $=14.84$, respectively. Accordingly, it can be said that both the students of the experimental group where activity-based teaching is applied and the students of the control group where program-based teaching is applied have an increase in the level of academic success in the easy question test map skill.

Directional analysis of variance results on whether these changes observed after the experiment showed a significant difference in the level of academic achievement in the easy question test of students subjected to two separate experimental processes are given in Table- 2 .

Table 2

Map Skills Easy Pretest-Posttest Anova Results of Success Scores

\begin{tabular}{llllll}
\hline Source of Variance & $\begin{array}{l}\text { Sum of } \\
\text { squares }\end{array}$ & $\mathrm{df}$ & Mean square $\mathrm{F}$ & $\mathrm{p}$ \\
\hline Between Groups & 2448.291 & 59 & & & \\
\hline Group (E/C) & 33.287 & 1 & 33.287 & .799 & .375 \\
\hline Error & 2415.004 & 58 & 41.638 & & \\
\hline Intergroup & 254.374 & 60 & & & \\
\hline $\begin{array}{l}\text { Measure (Pretest- } \\
\text { Posttest) }\end{array}$ & 53.883 & 1 & 53.883 & 16.929 & .000 \\
\hline Group* Measure & 15.883 & 1 & 15.883 & 4.990 & .029 \\
\hline Error & 184.608 & 58 & 3.183 & & \\
\hline Total & 2702.665 & 119 & & & \\
\hline
\end{tabular}

When the table 2 is examined, the findings of the previously mentioned hypotheses of the research can be explained as given below. There is no significant difference between the academic achievement scores of the pre-experiment and post-experiment preliminary and posttest easy question test of the experiment and control group. $\left.F_{(1-58)}=.779 ; p>.05\right)$. This finding shows that students in the experimental and control groups are "similar in their level of academic achievement in the test without distinction of measurement (pre and post the experiment)". 
In relation to students ' map skill easy question test academic achievements, there is a significant difference between the pretest- posttest average success scores. $\left.\mathrm{F}_{(1-58)}=16,929 ; \mathrm{p}<.05\right)$. This finding is that students ' easy question test "can be interpreted as their academic success varies depending on the teaching model applied", without distinction of group.

In Table 2 the analysis according to the results, the model was implemented in two separate experimental and control groups where students map skills instructional academic achievement scores showed significant differences before and after the experiment test easy questions, that is, the different process groups (experimental and control group) repeated measures factors with the effects of academic achievement on the ability to map Test easy questions levels was found to be significant $\left.\mathrm{F}_{(1-58)}=4.990 ; \mathrm{p}<.05\right)$. This finding shows that applying activity-based teaching and program-based teaching methods have different effects on improving students ' ability to map easy question test academic achievement. Map skill easy question test activity-based teaching, which has seen a greater increase in academic achievement scores than before the experiment, seems to be more effective in increasing students ' success in map skill easy questions than program-based teaching.

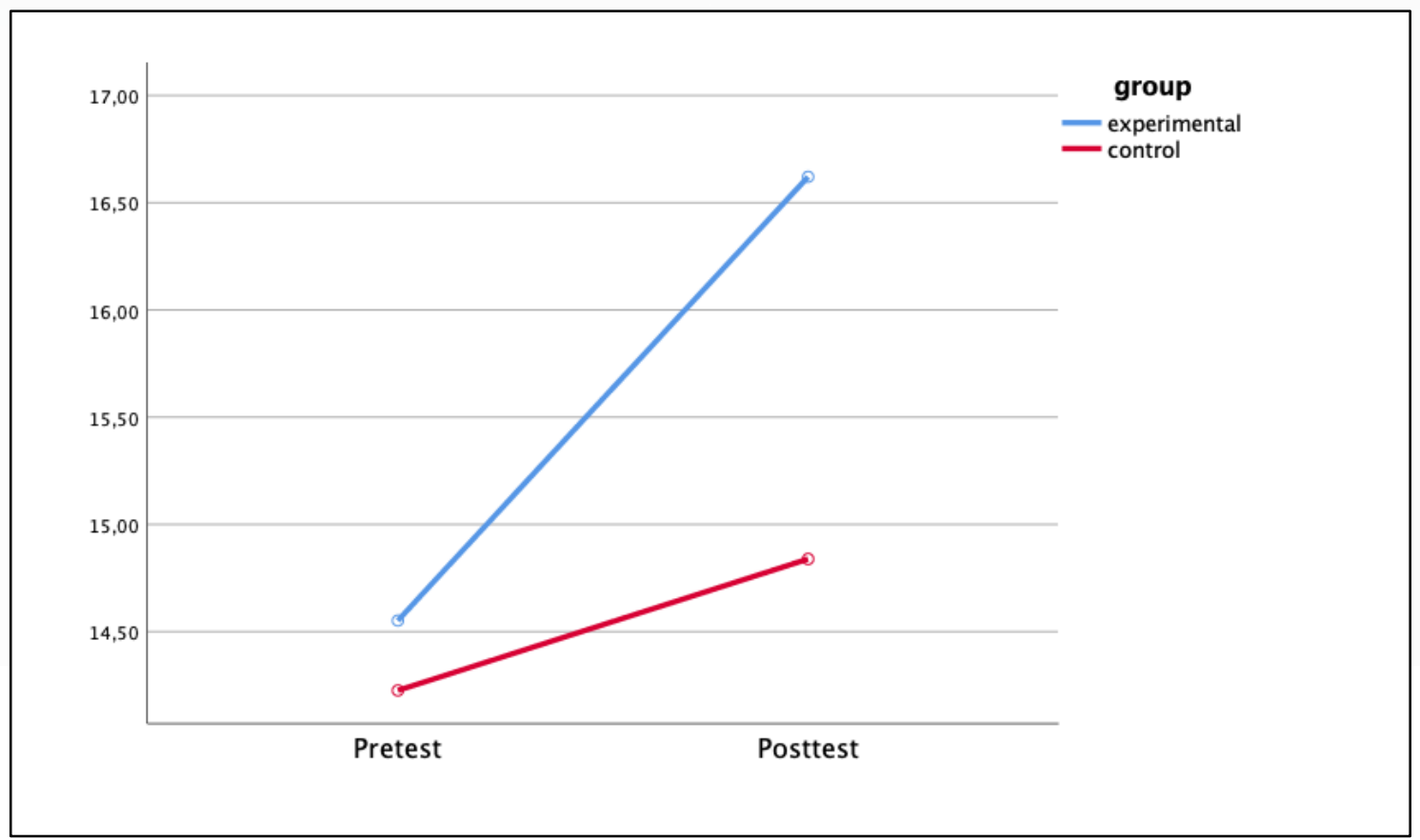

Figure 1. Pretest-posttest average scores of the experiment and control group for easy testing

\section{Findings and Comments on the Second Sub-Problem}

In the analysis of the second sub-problem of the study, it was investigated whether the test and control group Students' map skill test medium difficulty question size scores differed according to groups (experiment-control), measurements (pretest-posttest) and their common effect. The results of the analysis are given in Table 3-4. Map skill students' average score and standard 
deviation values obtained from the medium difficulty question size success test are given in Table 3.

Table 3

Pretest-Posttest Average Score and Standard Deviation Values That Students Receive From the Map Skills Average Difficulty Achievement Test

\begin{tabular}{lllllll}
\hline \multirow{2}{*}{ roup } & Pretest & \multicolumn{5}{c}{ Posttest } \\
\cline { 2 - 8 } & $\mathrm{N}$ & $\overline{\mathrm{X}}$ & $\mathrm{S}$ & $\mathrm{N}$ & $\overline{\mathrm{X}}$ & $\mathrm{S}$ \\
\hline Experimental & 29 & 16.66 & 8.05 & 29 & 18.82 & 7.86 \\
\hline Control & 31 & 17.26 & 7.78 & 31 & 17.77 & 8,18 \\
\hline
\end{tabular}

As can be seen in Table 3, the average score of the map skill average difficulty success test before the experiment was $\bar{X}=16.66$ of the students of the experimental group, where the teaching model based on map activity was applied, while this value was $=18.82$ after the experiment. The same scores of students in the control group where program-based teaching is applied are $\bar{X}=17.26$ and

$\overline{\mathrm{X}}=17.77$, respectively.

Academic achievement of students exposed to two separate experimental process intermediate levels of test questions before the experiment, the experiment observed after the change in question showed a significant difference of that twoway variance analysis results are given in Table 4.

Table 4

Map Skills Average Difficulty Test Anova Results of Pretes -Posttest Success Scores

\begin{tabular}{llllll}
\hline Source of Variance & $\begin{array}{l}\text { Sum of } \\
\text { squares }\end{array}$ & $\mathrm{df}$ & Mean square F & $\mathrm{p}$ \\
\hline Between Groups & 7123.625 & 59 & & & \\
\hline Group (E/C) & 1.520 & 1 & 1.520 & .012 & .912 \\
\hline Error & 7122.105 & 58 & 122.795 & & \\
\hline Intergroup & 322.644 & 60 & & & \\
\hline $\begin{array}{l}\text { Measure (Pretest- } 54.152 \\
\text { Posttest) }\end{array}$ & 1 & 54.152 & 12.668 & .001 \\
\hline Group* Measure & 20.552 & 1 & 20.552 & 4.808 & .032 \\
\hline Error & 247.940 & 58 & 4.275 & & \\
\hline Total & 7446.269 & 119 & & & \\
\hline
\end{tabular}

There is no significant difference between the academic achievement scores of the pre-experiment and post-experiment pretest and posttest intermediate question difficulty test of the experiment and control group $\left(\mathrm{F}_{(1-58)}=.012 ; \mathrm{p}>.05\right)$. This finding shows that students in the experimental and control groups are similar in their medium difficulty question test academic achievement levels without making a measurement distinction (pre and post experiment).

In relation to students' map skill moderate difficulty question test academic achievements, there is a significant difference between pretest - posttest average success scores $\left(\mathrm{F}_{(1-58)}=12.668 ; \mathrm{p}<.05\right)$. This finding can be interpreted as the academic achievement of students on the medium difficulty question test, without dividing the group, varies depending on the teaching model applied. 
According to the results of the "analysis " in table 4, it was found that the common effects of map skills on academic achievement scores of intermediate difficulty question test students of the experimental and control group in which two separate teaching models were applied were significant $\left(\mathrm{F}_{(1-58)}=4.808 ; \mathrm{p}<.05\right)$. This finding shows that applying activity-based teaching and program-based teaching methods have different effects on improving students' ability to map medium difficulty question test academic achievement. Map skill medium difficulty question test activity-based teaching, which has seen a greater increase in academic achievement scores than before the experiment, seems to be more effective in increasing students ' success in map skill medium difficulty questions than program-based teaching.

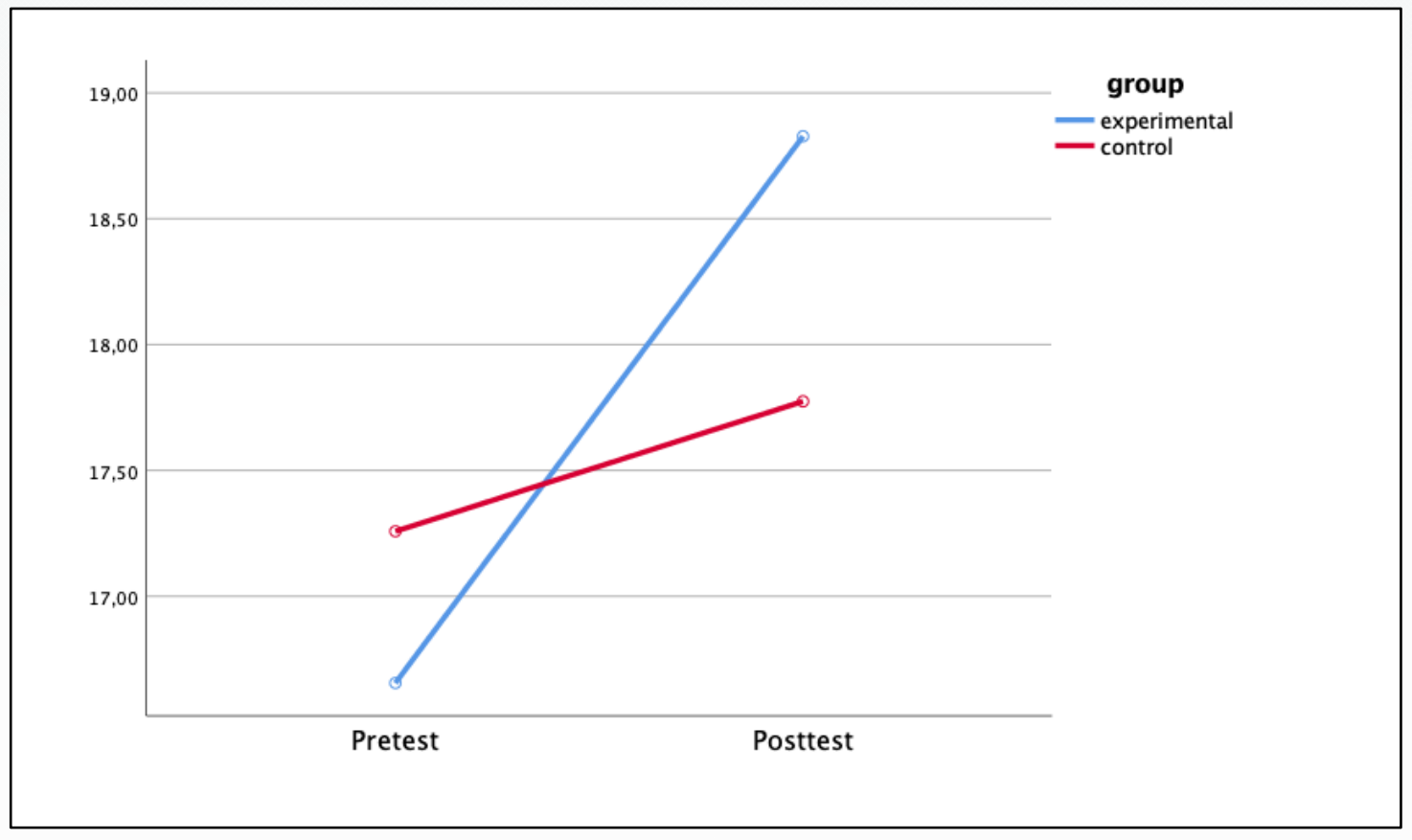

Figure 2. Pretest-posttest average scores of the experimental and control group on the medium-difficulty test

\section{Findings and Comments on the Third Sub-Problem}

In the analysis of the third sub-problem of the study, it was investigated whether the map skill test difficult question size scores of experimental and control group students differed according to groups (experiment-control), measurements (pretest-posttest) and their effect. The results of the analysis are given in Table 5-6.

Map skill of student's difficult question size pretest-posttest average score and standard deviation values obtained from the success test are given in Table-5.

Table 5

Pretest-Posttest Average Score and Standard Deviation Values That Student Receive From the Difficult Achievement Test Of Map Skills 


\begin{tabular}{lllllll}
\hline \multirow{2}{*}{ Group } & \multicolumn{3}{l}{ Pretest } & \multicolumn{4}{l}{ Posttest } \\
\cline { 2 - 7 } & $\mathrm{N}$ & $\overline{\mathrm{X}}$ & $\mathrm{S}$ & $\mathrm{N}$ & $\overline{\mathrm{X}}$ & $\mathrm{S}$ \\
\hline Experimental & 29 & 12.38 & 10.23 & 29 & 16.79 & 12.96 \\
\hline Control & 31 & 10.58 & 9.40 & 31 & 9.77 & 10.11 \\
\hline
\end{tabular}

As can be seen in Table 5, the average score of the test group students who applied the teaching model based on map activities before the experiment was $\bar{X}=12.38$, while this value was $\bar{X}=16.79$ after the experiment. The same scores of students in the control group where program-based teaching is applied are $\bar{X}=10.58$ and $=9.77$, respectively.

Academic achievement levels of students exposed to two separate experimental process difficult test questions before the experiment, the experiment observed after the change in question showed a significant difference of that two-way variance analysis results are given in Table 6.

Table 6

Map Skills Difficult Test Pretest-Posttest Anova Results of Success Scores

\begin{tabular}{llllll}
\hline Source of Variance & $\begin{array}{l}\text { Sum of } \\
\text { squares }\end{array}$ & $\mathrm{df}$ & Mean square $\mathrm{F}$ & $\mathrm{p}$ \\
\hline Between Groups & 13.522 .091 & 59 & & & \\
\hline Group (E/C) & 582.474 & 1 & 582.474 & 2.611 & .112 \\
\hline Error & 12939.617 & 58 & 223.097 & & \\
\hline Intergroup & 710.58 & 60 & & & \\
\hline $\begin{array}{l}\text { Measure (Pretest- } 97.488 \\
\text { Posttest) }\end{array}$ & 1 & 97.488 & 13.827 & .000 \\
\hline Group* Measure & 204.155 & 1 & 204.155 & 28.956 & .000 \\
\hline Error & 408.937 & 58 & 7.051 & & \\
\hline Total & 14232,671 & 119 & & & \\
\hline
\end{tabular}

Test and control group pre-test and post-test pre-test and post-test map skill difficult question test there is no significant difference between academic achievement scores $\left(\mathrm{F}_{(1-58)}=2.611 ; \mathrm{p}>.05\right)$. This finding shows that students in the experimental and control groups are similar in their level of academic achievement in the difficult question size test without making a measurement distinction (pre and post experiment).

As for students' map skill difficult question test academic achievements, there is a significant difference between the success scores of the intermediate question pretest - posttest $\left(\mathrm{F}_{(1-58)}=13.827 ; \mathrm{p}<.05\right)$. This finding can be interpreted as the academic achievements of students on the difficult question test, without seperate the group, vary depending on the teaching model applied.

According to the results of the analysis in table 6, it was found that the common effects of map skills on academic achievement scores of difficult question test students of the experimental and control group in which two separate teaching models were applied were significant $\left(\mathrm{F}_{(1-58)}=28.956 ; \mathrm{p}<.05\right)$. This finding shows that applying activity-based teaching and program-based teaching methods have different effects in improving students' ability to map difficult question test academic achievements. Map skill difficult question test activity-based teaching, 
which has seen a greater increase in academic achievement scores than before the experiment, seems to be more effective in increasing students' map skill success on difficult questions than program-based teaching.

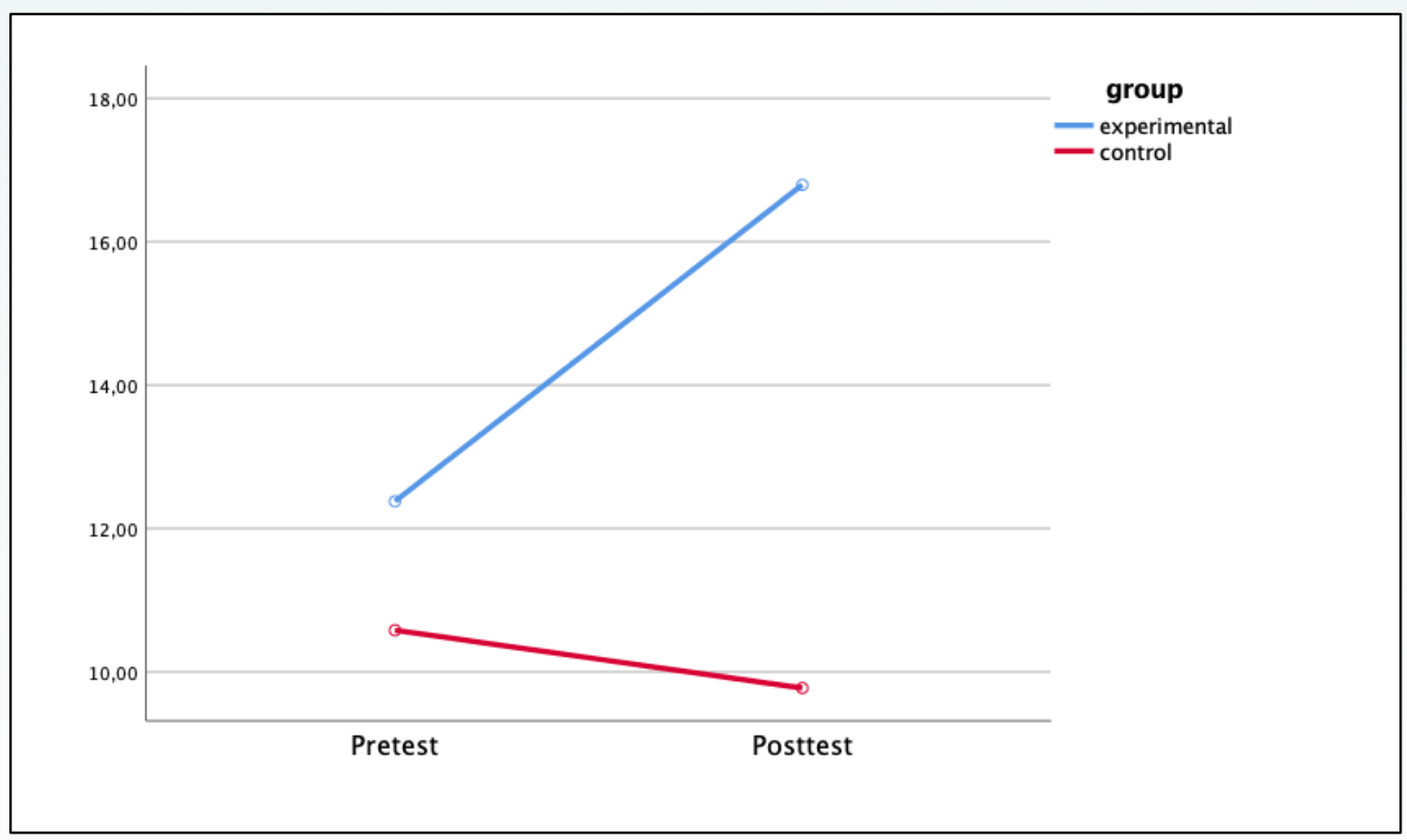

Figure 3. Pretest-posttest average scores of the experimental and control group for the difficult test

\section{Findings and Comments on the Fourth Sub-Problem}

In the analysis of the fourth sub-problem of the study, it was investigated whether the total scores of experiment and control group students on the map skill test differed according to groups (experiment-control), measurements (pretestposttest) and their effect. The results of the analysis are given in Table 7-8.

Pretest-posttest average score and standard deviation values obtained from the map skill total success test are given in Table-7.

Table 7

Average Score and Standard Deviation Values Obtained By Students from the Map Skills Total Success Test

\begin{tabular}{lllllll}
\hline \multirow{2}{*}{ Group } & \multicolumn{3}{l}{ Pretest } & \multicolumn{5}{c}{ Posttest } \\
\cline { 2 - 7 } & $\mathrm{N}$ & $\overline{\mathrm{X}}$ & $\mathrm{S}$ & $\mathrm{N}$ & $\overline{\mathrm{X}}$ & $\mathrm{S}$ \\
\hline Experimental & 29 & 43.59 & 20.49 & 29 & 52.24 & 23.09 \\
\hline Control & 31 & 42.06 & 20.47 & 31 & 42.38 & 21.13 \\
\hline
\end{tabular}

As can be seen in Table 7, the average score of the total success test of the map skill of the students of the experimental group in which the teaching model based on map activity was applied was $\bar{X}=43.59$, while this value was $\bar{X}=52.24$ after the experiment. The same scores of students in the control group where Program-based teaching is applied are $\bar{X}=42.06$ and $\bar{X}=42.38$, respectively. 
Total students exposed to academic achievement levels in two separate experimental process map skills tests before the experiment, the experiment observed after the change in question showed a significant difference of that twoway variance analysis results are given in table 8.

Table 8

Anova Results of Map Skills Test Pretest - Posttest Total Success Scores

\begin{tabular}{llllll}
\hline Source of Variance & $\begin{array}{l}\text { Sum of } \\
\text { squares }\end{array}$ & $\mathrm{df}$ & \multicolumn{2}{l}{ Mean square F } & $\mathrm{p}$ \\
\hline Between Groups & & 59 & & & \\
\hline Group (E/C) & 969.517 & 1 & 969.517 & 1.079 & .303 \\
\hline Error & 52127.908 & 58 & 898.757 & & \\
\hline Intergroup & 60 & & & \\
\hline $\begin{array}{l}\text { Measure (Pretest- 603.829 } \\
\text { Posttest) }\end{array}$ & 1 & 603.829 & 65.873 & .000 \\
\hline Group* Measure & 520.162 & 1 & 520.162 & 56.745 & .000 \\
\hline Error & 531.663 & 58 & 9.167 & & \\
\hline Total & 119 & & & \\
\hline
\end{tabular}

There is no significant difference between the total academic achievement scores of the experiment and control group pre-experiment and post-experiment pre-post test map skill $\left(\mathrm{F}_{(1-58)}=1.079 ; \mathrm{p}>.05\right)$. This finding shows that the total academic achievement levels of the map Skill Test of the students in the experiment and control groups are similar without dividing the measurement (pre and post experiment).

In relation to the academic achievements of students' map skill, there is a significant difference between the average success scores of pretest - posttest $\left(\mathrm{F}_{(1-}\right.$ $58)=65.873 ; p<.05)$. This finding can be interpreted as the academic success of the map skill test of students without group separation varies depending on the teaching model applied.

According to the results of the analysis in table 8, it was found that the common effects of the map skill test on the total academic achievement scores of the students of the experimental and control group, where two separate teaching models were applied, were significant $\left(\mathrm{F}_{(1-58)}=56.745 ; \mathrm{p}<.05\right)$. This finding shows that applying activity-based teaching and program-based teaching methods have different effects in improving students' map skill test academic achievement. Map skill test activitybased teaching, which has seen a greater increase in total academic achievement scores than before the experiment, seems to be more effective in increasing students' map skill success than program-based teaching. 
Kaldybekova, R; Aksoy, B;; Abdymanapov; B. (2021). Impact of activity-based map literacy skills.....

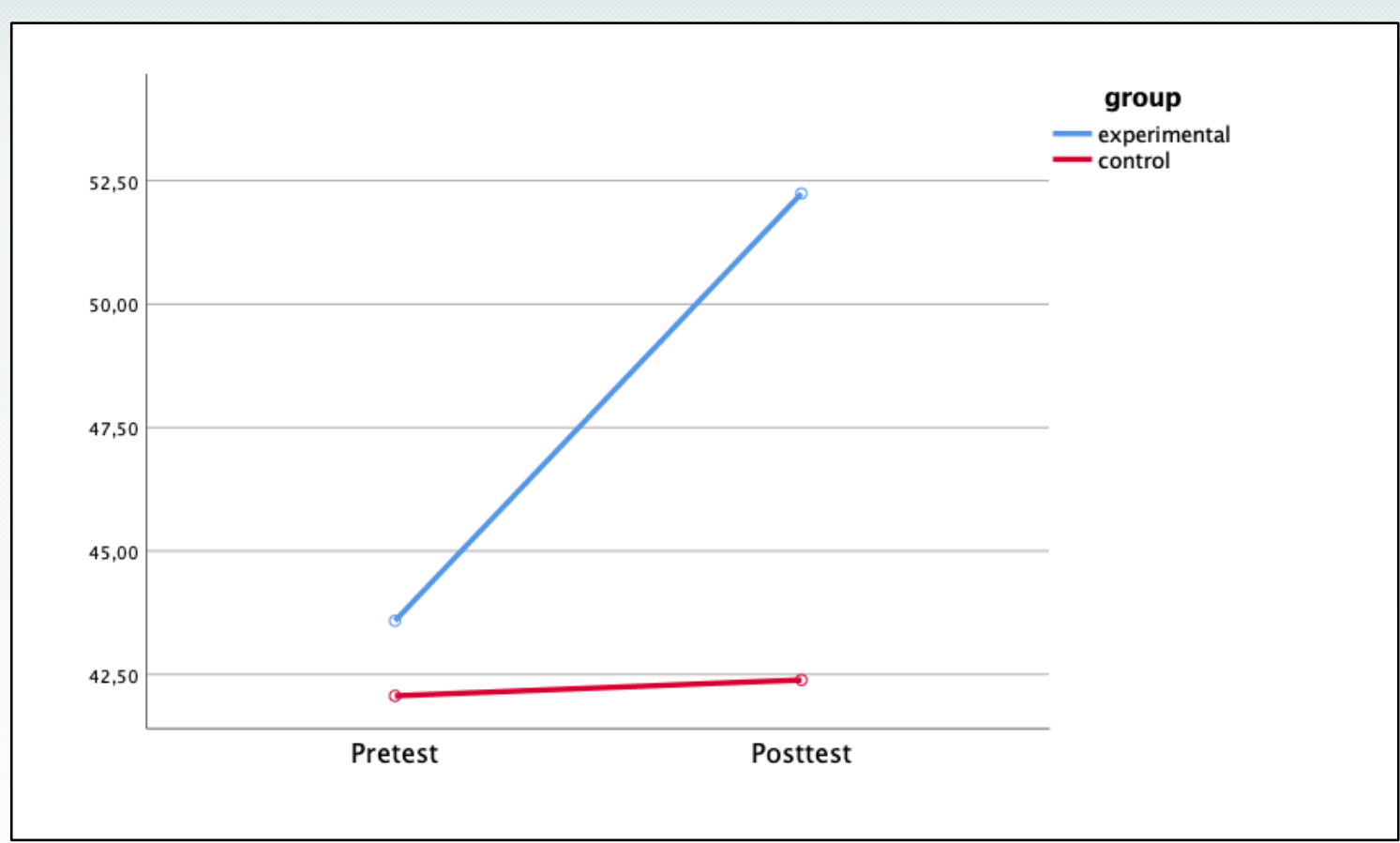

Figure 4. Pretest-posttest average scores for the total scores of the test success test of map skills of the experiment and control group.

\section{Result and Discussion}

According to the research results based on the instructional model was implemented with the experimental group activities where students in the programbased instruction applied to a control group showed significant differences before and after the experiment, students map skills test academic achievement scores easy questions, that is, the different process groups (experimental and control group) with repeated measures on the effects of academic achievement levels test questions have the ability to easily map factors was found to be significant. Aksoy (2019) determined that there is a positive and moderate relationship between the map literacy levels of geography undergraduate students and the frequency of using maps, the frequency of activity with maps and the variables of interest in geography.

Research results showed that the map skills of experimental group students who applied the activity-based learning model and control group students who applied program-based learning were significant compared to the common effects of group and measurement factors. Erol (2017) determined the map literacy levels of secondary school students as intermediate level. It has been concluded that the lack of sufficient number of map literacy activities in the student workbooks of the Social Studies course negatively affects the development of this skill.

According to another result of the study, it was determined that the students of the experimental group where the activity-based learning model was applied and the control group students where program-based learning was applied had map skills difficult question test academic success scores differed significantly according 
to the effect of the group and measurement factors. In his research, Koç \& Karatekin (2015) found that the map knowledge levels of Social Studies teacher candidates are close to the lower level, and that their ability to process maps, read and interpret maps, draw draft maps and use maps is moderate. According to the results of Koç \& Çifçi (2016) research, classroom teacher candidates have a moderate level of map literacy.

The results of the research showed that the total academic achievement scores of the map skill test of the experimental group students who applied the activity-based teaching model and the control group students who applied the program-based teaching were significant according to the effect of the group and measurement factors. These results are similar to the results of Aksoy (2013), Koç \& Karatekin (2015), Koç \& Çiftçi (2016), Koç, Aksoy \& Çiftçi (2017), Aksoy (2019), Aksoy and Ablak (2019), Kızllçaoğlu (2007) studies. Sönmez \& Aksoy (2012) it was determined that the map skill level of the students receiving private school education from the primary school students was better than the students receiving public school education. In the same study, it was determined that the map skill levels of students whose settlement is metropolitan were higher than those of students whose settlement type is city. Again, Kaldybekova \& Beykitova, 2019; Isatayeva \& Tukhtasinov, 2020; Kaldybekova \& Abdymanapov, 2020 studies have also reached conclusions supporting this result of the study.

\section{Suggestions}

Research results have shown that the teaching model enriched by activities is more effective in developing students' map literacy skills in the secondary school geography course. Based on this result, it is recommended that the map skills attainments in the secondary school program be enriched with activities and practices.

\section{References}

Aksoy, B. (2013). Investigation of Mapping Skills of Pre-Service Teachers as Regards to Various Parameters. Educational Research and Reviews, 8(4), 134-143.

Aksoy, B., Kılıçoğlu, G. \& Ablak, S. (2015). The Relation of 11-14 Years Old Students Map Skills and Their Achievement Levels in Mathematics. Journal of World of Turks, 7(2), $59-71$

Aksoy, B. \& Ablak, S. (2019). An Evaluation of map literacy of social studies preservice teachers. Participatory Educational Research (PER), 6(2), 158-168.

Aksoy. B. (2019). Determination of map literacy of undergraduate geography students, Review of International Geographical Education Online, 9(3), 591-603.

Alimzhanova, A. (2011). Qızıqtı geografiya. Almaty: Times.

Buckley, A. R., Muehrcke, P. C. \& Muehrcke, J. O. (2011). MapUse: Reading, Analysis and Interpretation. Redlands, CA: Esri Press.

Beysenbayeva, M. B., Kotyakhova, G. M. \& Larionova G. S. (2009). Sbornik testovykh zadaniy po geografii. 6-9 klassy. Kokshetau: Keleşek-2030. 
Kaldybekova, R.; Aksoy, B.; Abdymanapov; B. (2021). Impact of activity-based map literacy skills.....

Beysenbayeva, M. B. (2015). Sbornik testovykh zadaniy po geografii. Kokshetau: Keleșek2030.

Bibik, A. Ye. (1975). Metodika obucheniya geografii $v$ sredney shkole. Moskva: Prosveshcheniye.

Carswell, R. J. B. (1971). The Role of the user in the map communication process: children's abilities in topographic map reading. Cartographica. The International Journal for Geographic Information and Geovisualization, 8(2), 40-45.

Catling, S. J. (1998). Geographical Work in Primary and Middle Schools. Sheffield: Geographical Association.

Clarke, D. (2003). Are you functionally map literate?, Proceedings of the 21st International Cartographic Conference (ICC). South Africa: Durban. 10-16 August, 713-719.

Cohen, L., Manion, L., \& Marrison, K. (2000). Research methods in education (5th Ed.). London: Routledge \& Falmer.

Erol, H. (2017). An Evaluation on Secondary School Students' Map Literacy Skills. Anadolu Journal of Educational Sciences International, 7(3), 425-457.

Fedorova, T. I. (2015). Geografiya. Sbornik testovykh zadaniy. Kokshetau: Keleşek-2030.

Fraenkel, J. R., \& Wallen, N. E. (2006). How to design and evaluate research in education. New York: McGraw-Hill.

Geografiya päninen test jïnağı. (2005). Astana: Bilim berw men testilewdiñ memlekettik standarttarınıñ ulttıq ortalı̆̆ı.

Gerber, R. \& Wilson, P. (1989). Using maps well in the geography classroom. In J. Fien., R. Gerber \& P. Wilson (Ed.), The geography teacher's guide to the classroom. Melbourne: Macmillan.

Gilmartin, P. P. \& Patton, J. C. (1984). Comparing the sexes on spatial abilities: map-use skills. Annals of the Association of American Geographers, 74(4), 605-619.

Golledge, R. G., Marsh, M. \& Battersby, S. (2008). Matching geospatial concepts with geographic educational needs. Geographical Research, 46(1), 85-98.

Gökçe, N. (2015). Social Studies in Improving Students' Map Skill: Teachers' Opinions. Educational Sciences: Theory \& Practice, 15(5), 1345-1362.

Gryunberg, G. YU., Lapkina, N. A., Malakhov, N. V. \& Fel'dman, Ye. S. (1991). Kartografiya sosnovami topografi. Moskva: Prosveshcheniye.

Isatayeva G.K. \& Tukhtasinov U.I. (2020). Geografiyalıq kartalardı bilimniñ közi retinde qoldanw. Örlew-Şımkent, 44(2), 28-37.

Jemirova, M. Ye. (2017). Ispol'zovaniye lichnostno-razvivayushchikh situatsiy v protsesse organizatsii deyatel'nosti mladshikh shkol'nikov s geoizobrazheniyami. Geografiya v shkole, 4, 47-53.

Kaldybekova R. \& Beykitova A. (2019). Formirovaniye navykov myshleniya obuchayushchikhsya cherez kartagraficheskuyu deyatel'nost'. Pedagogika $i$ psikhologiya, 41 (4), 169-180

Kaldybekova, R. \& Abdymanapov, B. (2020). Geografiyalıq kartalardıñ joğarı deñgeydegi oylaw dağdıların qalıptastırwdağı roli. Kazakstannnıñ pedagogïkalıq ğılımdar akademïyasınıñ xabarşısı, 2, 93-100. 
Kartal, F. \& Koç, H. (2017). Examination of Map Literacy Levels of Secondary Levels Students (9 th Grade) in Terms of Certain Variables, Eastern Geographical Review, 22(37), 179198.

Kızılçaoğlu, A. (2007). A pedagogical overview of map skills. The Journal of Institute of Social Sciences, 18, 341-358.

Klimanova, O. A. \& Naumov, A. S. (2002). Olimpiady po geografii, 6-11 klass. Moskva: Drofa.

Koç, H. (2010). Map perception and usage in geography education. National Education, 87, 146-158.

Koç, H. \& Demir, S. B. (2014). Developing valid and reliable map literacy scale. Review of International Geographical Education, 4(2), 120-136.

Koç, H. \& Karatekin, K. (2015). An examination of map literacy levels of prospective social studies teachers in terms of various variables. $4^{\text {th }}$ USBES. Bolu.

Koç, H. \& Çifçi, T. (2016). An investigation into map literacy levels of elementary school teacher candidates based on various variables, Marmara Geographical Review, 34, 920.

Koç, H., Aksoy, B. \& Çifçi, T. (2017) An examination of map literacy levels of students from various undergraduate programmes according to several variables: Cumhuriyet university sample. Erzincan University Journal of Education Faculty, 31(1), 301-321.

Kress, G. (2003). Literacy in the new media age. London: Routledge.

Kudinov, V. S. (2017). Uroki oriyentirovaniya v shkole. Volgograd: Knaub.

Kussainov, G. M. (2012). Pedagogical technology of a modern school. Astana: Oqwliq.

Liben, L. \& Downs, R. (1989). Understanding Maps as Symbols: the Development of Map Concepts in Children. New York: Academic Press.

Lodico, M. G., Spaulding, D. T., \& Voegtle, K. H. (2006). Methods in educational research: From theory to practice. San Francisco: Jossey-Bass Publishers.

Lyutyj, A. A. (2002). Yazyk karty: sushchnost', sistema, funkcii. Moskva: GEOS.

Mac Eachren, M. (2004). How Maps Work. New York: The Guilford Press.

McClure, R. W. (1992). A conceptual model for map skills curriculum development based upon a cognitive field theory philosophy (Unpublished Doctoral Dissertation). Oklahoma State University, Oklahoma.

Olson, J. M. (1976). A coordinated approach to map communication improvement. The American Cartographer, 3(2), 151-159.

Petrova, N. (1999). 2500 testov i proverochnykh rabot po geografii dlya shkol'nikov. Moskva: Drofa.

Richard, B., Schultz, J. \&Kerski J. \&Todd, C. P. (2008). The use of virtual globes as a spatial teaching tool with suggestions for meta data standards. Journal of Geography, 107(1), 27-34.

Rautenbach, V. Coetzee, S. \& Çöltekin, A. (2017). Development and evaluation of a specialized task taxonomy for spatial planning - A map literacy experiment with topographic maps, ISPRS Journal of Photogrammetry and Remote Sensing, 127, 16-26.

Salishchev, K. A. (1990). Kartovedeniye. Moskva: Moskovskiy gosudarstvennyy universitet. 
Sönmez, Ö.F. \& Aksoy, B. (2012). Determination of primary education secondary stage students' map skill levels. Turkish Studies-International Periodical for the Languages, Literature and History of Turkish or Turkic 7(1), 1905-1924.

Sönmez, Ö.F. ve Aksoy, B. (2013). Cumhuriyetten Günümüze İlköğretim Programlarında Harita Becerileri. Türkiye Sosyal Araştırmalar Dergisi 17(1), 269-288.

Sukhinin, S. (2019). Competence of the cartographic literacy of schoolchildren: essence and methodological foundations of the formation. Problems of Continuous Geographic Education and Cartography, (29), 87-95.

Tabachnick, B. G., \& Fidell, L. S. (2013). Using multivariate statistics (6th Ed.). Boston: Pearson Education.

Tokpanov, Ye. A. \& Mazbayev, O. B. (2012). Osnovy kartografii i topografii. Almaty: DAUR.

Vostokova, A. V., Koshel', S. M. \& Ushakova, L. A. (2002). Oformleniye kart. Komp'yuternyy dizayn. Moskva: Aspekt Press.

Weeden, P. (1997). Learning through maps. D. Tilbury \& M. Williams (Eds.), Teaching and learning geography, In (pp. 168-179). London: Routledge.

White, S. H. (1995). An examination of the effects of mixed-age grouping on learning map reading skills (Unpublished Dissertation), Texas: A \& M University.

Wiegand, P. (2006). Learning and Teaching with Maps. New York: Routledge.

Wood, D. (1992). The Power of Maps. New York: The Guilford.

Yevdokimov, V. I. (2011). Sbornik zadaniy i uprazhneniy po geografii. Moskva:Aspekt Press.

Zarutskaya, I. P. \& Svatkova, T. G. (1982). Proektirovanie isostavlenie kart. Obshchegeograficheskie karty. Moskva: Moskovskiy gosudarstvennyy universitet.

Zhemerov, A. O. (2011). Zadachi po topografii i kartografii na uchenicheskih geograficheskih olimpiadah. Geografiya v shkole, 10, 44-48.

\section{Biographical Statements}

Raziya KALDYBEKOVA Raziya Kaldybekova is a doctoral student at Abai Kazakh National Pedagogical University. Her research interests are Geography Education, Economic and Social Geography.

Bülent AKSOY is a professor at Gazi University. His research interests are Geography Education, Social Studies Education and Political Geography studies.

Bahadurkhan ABDYMANAPOV Bahadurkhan Abdymanapov is an associate professor at Abai Kazakh National Pedagogical University. His research interests are Geography Education, Natural Sciences and Ecology. 